\title{
Pengaruh Penerapan Media UnoMath untuk Meningkatkan Kemampuan Komunikasi Matematis dan Kemandirian Belajar Siswa
}

\author{
Asep Robiana ${ }^{1 *}$ dan Hendri Handoko ${ }^{2}$ \\ $1^{*, 2 J u r u s a n}$ Tadris Matematika, IAIN Syekh Nurjati Cirebon \\ Jalan Perjuangan By Pass Sunyaragi, Cirebon, Jawa Barat, Indonesia \\ 1*aseprobiana21@gmail.com; ${ }^{2}$ hendrihandoko.iain.crb@gmail.com
}

Artikel diterima: 05-05-2020, direvisi: 27-09-2020, diterbitkan: 30-09-2020

\begin{abstract}
Abstrak
Komunikasi matematis dan kemandirian belajar merupakan hal yang sangat penting dimiliki oleh siswa dan merupakan bagian esensial dari matematika. Masih rendahnya kemampuan matematis dan kemandirian belajar siswa di lapangan, guru harus mengupayakan pembelajaran dengan menerapkan media pembelajaran yang dapat memberikan peluang dan mendorong siswa untuk melatih kemampuan komunikasi matematis dan kemandirian belajar siswa, salah satu media pembelajaran tersebut yaitu media UnoMath. Tujuan Penelitian ini yaitu untuk mengetahui pengaruh penerapan media UnoMath terhadap peningkatan kemampuan komunikasi matematis dan kemandirian belajar siswa. Metode yang digunakan pada penelitian ini adalah penelitian eksperimen dengan pendekatan kuantitatif dengan desain pretest-posttest control group, penelitian ini dilakukan di SMP Negeri 3 Rajagaluh, kelas VIII A sebanyak 21 orang dan VIII C sebanyak 31 orang sebagai sampel, dengan instrumen tes dan angket. Teknik analisis data yang digunakan yaitu uji-t dengan berbantuan SPSS. Hasil penelitian menunjukkan adanya peningkatan kemampuan komunikasi matematis dan kemandirian belajar siswa.

Kata Kunci: Kemampuan Komunikasi Matematis, Kemandirian Belajar, UnoMath.

\section{Effect of Application of UnoMath Media to Improve Mathematical Communication Skills and Self-Regulated Learning}

Abstract

Mathematical communication and self-regulated learning are very important things for students and are an essential part of mathematics. Still low mathematical abilities and selfregulated learning student in the field, teachers must strive for learning by applying learning media that can provide opportunities and encourage students to practice mathematical communication skills and self-regulated learning student, one of these learning media is UnoMath media. The purpose of this study was to determine the effect of the application of UnoMath media on improving students' mathematical communication skills and self-regulated learning. The method used in this research is experimental research with a quantitative approach with pretest-posttest control group design, this research was conducted at SMP Negeri 3 Rajagaluh, class VIII $A$ as many as 21 people and VIII C as many as 31 people as a sample, with test instruments and questionnaires. The data analysis technique used is the t-test assisted by SPSS. The results showed an increase in mathematical communication skills and selfregulated learning student.

Keywords: Mathematical Communication Skills, Self-Regulated Learning, UnoMath.
\end{abstract}




\section{Pendahuluan}

Menurut Handoko (2018), matematika merupakan induk ilmu pengetahuan yang harus mampu mencetak sumber daya manusia yang memiliki karakter unggul dan siap saing. Peningkatan kemampuan beripikir yang kreatif, disiplin, dan kerjasama pada masa kehidupan yang modern dan kompetitif saat ini merupakan fungsi dari matematika (Handoko, 2017; Sundawan, Irmawan, \& Sulaiman, 2019).

Mata pelajaran yang memiliki peranan penting di sekolah yaitu matematika (Afriansyah, Puspitasari, Luritawaty, Mardiani, \& Sundayana, 2019), terbukti dengan waktu jam pelajaran sekolah yang lebih banyak dibandingkan dengan mata pelajaran lainnya. Sebaliknya, dengan waktu yang diberikan lebih banyak dari mata pelajaran yang lain dalam kegiatan belajar mengajar, tetapi pada kenyataannya pencapaian belajar siswa masih belum maksimal pada pembelajaran. Menurut Sumliyah (2019) berpendapat bahwa matematika merupakan dasar dan pendukung ilmu lain seingga matematika merupakan induk ilmu dan sangat penting untuk dipelajari.

Belajar untuk berkomunikasi (mathematical communication) merupakan salah satu Tujuan pembelajaran matematika yang dirumuskan oleh National Council of Teacher of Mathematics (2000; Asmara \& Afriansyah, 2018). Berdasarkan hasil survei TIMSS (Trends in International Mathematics and Science Study) menunjukkan bahwa kemampuan dalam pembelajaran matematika siswa Indonesia masih di bawah rata-rata international. Hasil survei TIMSS (2011; Mulyo, Sari, \& Syarifuddin, 2019) yang diraih siswa Indonesia adalah 400 berada di kategori rendah, masih belum memenuhi dan sangat jauh dari kategori mahir yang harus mecapai skor 625. Ketika ditinjau dari konten yang diujikan untuk penilaian kognitif dalam TIMSS, siswa Indonesia memperoleh skor pada aspek pengetahuan dengan rata-rata skor 378, aspek penerapan dengan skor 384, dan aspek penalaran dengan skor 388 . Selain itu, dari segi penilaian konten matematik yang diujikan, siswa Indonesia pada aspek bilangan mendapatkan skor rata-rata 375 , aspek aljabar 392, aspek geometri 377, dan aspek data dan peluang 376. Berdasarkan hasil yang didapat, terbukti prestasi belajar matematika siswa SMP di Indonesia masih jauh di bawah standar rata-rata artinya masih rendah di taraf internasional.

Pemerintah Indonesia selalu berupaya untuk menyelesaikan permasalahan di atas, salah satunya dengan melakukan penyempurnaan kurikulum 2013 agar mutu pendidikan mengalami peningkatan (Rizkianto \& Santosa, 2017). Menekankan pada pentingnya komunikasi merupakan salah satu kelebihan yang terdapat pada kurikulum 2013.

Tujuan pembelajaran Matematika dari NCTM dan kurikulum 2013 sudah selaras, tetapi dalam pelaksanaannya masih belum maksimal akibatnya hasil yang diharapkan 
dari tujuan tersebut belum tercapai dengan yang diharapkan, terbukti dengan rendahnya prestasi belajar matematika siswa Indonesia di taraf International. Berdasarkan tujuan pembelajaran matematika yang sudah dibahas di atas, dapat dilihat bahwa kemampuan komunikasi matematis siswa adalah salah satu aspek yang ditekankan pada kurikulum 2013 dan NCTM.

Salah satu kemampuan yang harus dimiliki oleh siswa yaitu kemampuan komunikasi matematis (Dewi \& Afriansyah, 2018). Hal ini sesuai dengan yang terdapat dalam National Council of Teachers of Mathematics (NCTM, 2000) menyebutkan bahwa bagian penting dari matematika dan pendidikan matematika yaitu komunikasi. Pendapat tersebut memperkuat bahwa pada pembelajaran matematika penting adanya komunikasi. Melalui komunikasi, siswa mampu mengungkpakan gagasannya baik itu kepada pendidik maupun kepada peserta didik lainnya. Oleh karena itu, peningkatan kemampuan komunikasi matematis siswa harus lebih ditingkatkan lagi.

Di samping pentingnya kemampuan komunikasi matematis, ada sikap yang perlu dimiliki oleh seorang siswa salah satunya adalah kemandirian belajar. Indikator dari kemandirian belajar yaitu inisiatif, memonitor, mengatur, dan mengontrol belajar (Sumarno, 2003). Dengan mempunyai sikap tersebut, diharapkan siswa dapat terus meningkatkan kemampuan matematika dan dapat menggunakan ilmu matematika untuk menyelesaikan permasalahanpermasalahan yang dihadapi dalam hidupnya.

Pada pembelajaran saat ini siswa dituntut dan harus memiliki sikap kemandirian belajar (Nurhikmayati \& Sunendar, 2020). Menurut Nurhayati (2011) kemandirian merupakan suatu sikap seseorang yang didapat secara kumulatif selama perkembangan, seseorang tersebut akan terus menerus belajar untuk bersikap mandiri dalam menghadapi berbagai macam situasi di lingkungan, yang mengakibatkan individu tersebut pada akhirnya akan bisa berpikir dan bertindak sendiri. Di pihak lain, menurut Pannen (2001) peningkatan kemampuan yang dimiliki siswa untuk melaksanakan proses pembelajaran sendiri tanpa adanya ketergantungan terhadap seorang guru, teman sebaya, kelas, dan lain sebagainya. Besarnya tanggung jawab dan inisiatif siswa untuk selalu berperan aktif dan merencanakan pembelajaran, proses pembelajaran, dan menevaluasi pembelajaran merupakan penentuan seberapa besar tingkat kemandirian belajar seoarang siswa. Ketika siswa sangat berperan aktif dalam berbagai macam kegiatan tersebut maka semakin tinggi tingkat kemandirian belajar siswa tersebut.

Menurut Fahradina (2014) pada umumnya terdapat beberapa alasan penting mengenai kemandirian belajar bagi siswa yang ada saling terkait dengan kurikulum saat ini yaitu salah satunya siswa 
harus bisa menghadapi permasalahan di dalam kelas maupun di luar kelas (Afriansyah, 2013) yang semakin kompleks dan siswa diharapkan dapat mengurangi ketergantungan belajar dengan orang lain dalam meyelesaikan permasalahan dalam kehidupan sehari-hari. Berdasarkan pendapat para ahli di atas dapat disimpulkan bahwa siswa harus memiliki sikap kemandirian belajar pada saat proses pembelajaran sehingga siswa tidak lagi merasa ketergantungan terhadap guru yang mengakibatkan proses belajar mengajar menjadi tidak maksimal.

Menyadari akan pentingnya komunikasi matematis dan kemandirian belajar siswa, guru bisa menggunakan media pembelajaran yang dapat memberikan peluang dan mendorong siswa untuk melatih kemampuan komunikasi matematis dan kemandirian belajar siswa. Hal ini sesuai dengan pendapat Handoko (2019) bahwa media pembelajaran dapat mempermudah guru dalam mengajar dan membuat siswa merasa senang dan nyaman dalam pembelajaran di kelas.

Menurut Gerlach dan Ely (2015), manusia, materi, atau kajian yang membangun suatu kondisi yang membuat siswa mampu mendapatkan pengetahuan, keterampilan atau sikap merupakan cakupan media pembelajaran yang sangat luas. Sementara itu, menurut Gagne dan Brigs (2011) buku, tape-recorde, kaset, video kamera, film, slide (gambar bingkai), foto, gambar, grafik, televisi, dan komputer merupakan alat secara fisik untuk menyampaikan pembelajaran yang disebut dengan media pembelajaran.

Untuk meingkatkan kemampuan komunikasi matematis dan kemandirian belajar siswa diperlukan media pembelajaran yang tepat, kreatif dan inovatif serta membuat pembelajaran matematika menjadi lebih aktif dengan mengikutsertakan siswa dalam kegiatan belajar mengajar baik di dalam maupun di luar kelas (Tarlina \& Afriansyah, 2016). Salah satu media pembelajaran yang dapat mengikut sertakan siswa dalam pembelajaran matematika di dalam dan di luar kelas yaitu dengan menggunakan media permainan (Rahmatin, 2016). Permainan kartu UnoMath (Uno Mathematics) akan menciptakan suasana belajar yang menggembirakan sehingga tujuan pembelajaran matematika bisa tercapai.

Berdasarkan uraian sebelumnya, harapan diadakannya penelitian ini semoga semakin banyak media pembelajaran berisifat permainan yang kreatif dan inovatif untuk membuat suasana pembelajaran di dalam kelas lebih menyenangkan sehingga tujuan pembelajaran bisa tercapai dengan optimal. Oleh karena itu, tujuan penelitian ini adalah mengetahui pengaruh penerapan media Unomath terhadap peningkatan kemampuan komunikasi matematis dan kemandirian belajar siswa.

\section{Metode}

Mosharafa: Jumal Pendidikan Matematika Volume 9, Nomor 3, September 2020

Copyright $\odot 2020$ Mosharafa: Jurnal Pendidikan Matematika 
Jenis penelitian yang digunakan yaitu jenis penelitian dengan pendekatan kuantitatif dengan menggunakan metode eksperimen yaitu suatu penelitian yang mencari pengaruh dari sebuah variabel dengan variabel lain dalam kondisi yang terkontrol secara (Riduwan, 2010). Desain penelitian yang digunakan yaitu pretestposttest control group design. Penelitian ini dilaksanakan di SMP Negeri 3 Rajagaluh Kabupaten Majalengka Jawa Barat dari bulan Januari hingga Maret 2020. Populasi penelitian yaitu siswa kelas VIII SMP Negeri 3 Rajagaluh. Penentuan sampel dilakukan dengan menggunakan teknik purposive Sampling yaitu kelas VIII C sebagai kelas Eksperimen yang terdiri dari 21 siswa dan kelas VIII A sebagai kelas kontrol yang terdiri dari 31 siswa. Teknik pengumpulan data yang digunakan ada dua jenis yaitu tes berupa tes uraian untuk mengukur kemampuan komunikasi matematis siswa dan non tes yaitu berupa angket untuk mengukur kemandirian belajar siswa serta respon siswa terhadap media UnoMath.

Kemudian instrumen divalidasi oleh para expert dan diuji cobakan di sekolah yang sama dengan kelas yang berbeda yaitu kelas VIII B yang terdiri dari 26 siswa. Setelah melakukan uji coba, nilai siswa tersebut diolah kemudian diuji validitas setiap butir soal serta dicari tingkat kesukaran, daya pembeda, dan reliabilitas soal untuk melihat soal tersebut dapat digunakan atau tidak sebagai alat pengumpulan data.
Uji keefektifan media UnoMath menggunakan uji statistika independent sample $t$ test pada hasil pretest dan posttest kemampuan komunikasi matematis dan kemandirian belajar siswa. Kemampuan komunikasi matematis dan kemandirian belajar siswa dianalisis menggunakan uji regresi sederhana berdasarkan hasil angket respon media dan nilai posttest untuk mengetahui pengaruh penerapan media UnoMath terhadap kemampuan komunikasi matematis dan kemandirian belajar siswa.

\section{Hasil dan Pembahasan}

\section{A. Penerapan Media UnoMath dalam Pembelajaran}

1) Perancangan Desain UnoMath

Permainan kartu Uno merupakan inspirasi untuk konsep awal dari media pembelajaran UnoMath. Namun, ada beberapa kompenen kartu yang dimodifikasi pada media UnoMath sehingga fungsi dari kartu tersebut berbeda dengan bertujuan agar terjadi keselarasan dengan media pembelajaran yang dibuat. Tahap ini sebagai dasar pembuaatan produk media UnoMath.

2) Pembuatan Aturan Main, Soal dan Kunci Jawaban

Pada tahap ini peneliti membuat aturan permainan media UnoMath, soal beserta kunci jawaban. Dasar peraturan permainan media UnoMath dimodifikasi dengan permainan kartu UNO pada umumnya. Pada permainan kartu UNO umumnya meneyesuaikan angka dan warna (deal 
card) pada wild card sedangkan pada UnoMath selain menyesuaikan angka dan warna, peserta didik juga harus menjawab soal yang terdapat pada kartu UnoMath. Adapun soal dan kunci jawaban yang terdapat pada kartu UnoMath disesuaikan dengan materi yang terdapat di silabus mata pelajaran matematika tentang persamaan linear dua variabel. Soal-soal tersebut berbentuk uraian dan sudah terdapat kunci jawaban secara terpisah.

3) Pembuatan Backround dan Kartu

Pembuatan background pada kartu sendiri didesain dengan menggunakan aplikasi CorellDraw X7. Kartu UnoMath didesain semenarik mungkin agar siswa mendapatkan kesan yang baik pada media pembelajaran yang dibuat. Menyesuaikan dengan materi dan karakter siswa serta kejelasan dengan tulisan soal merupakan syarat dalam pemilihan warna yang tepat. Berikut peneliti uraikan kelengkapan permainan media UnoMath yaitu:

- 1 lembar aturan permainan

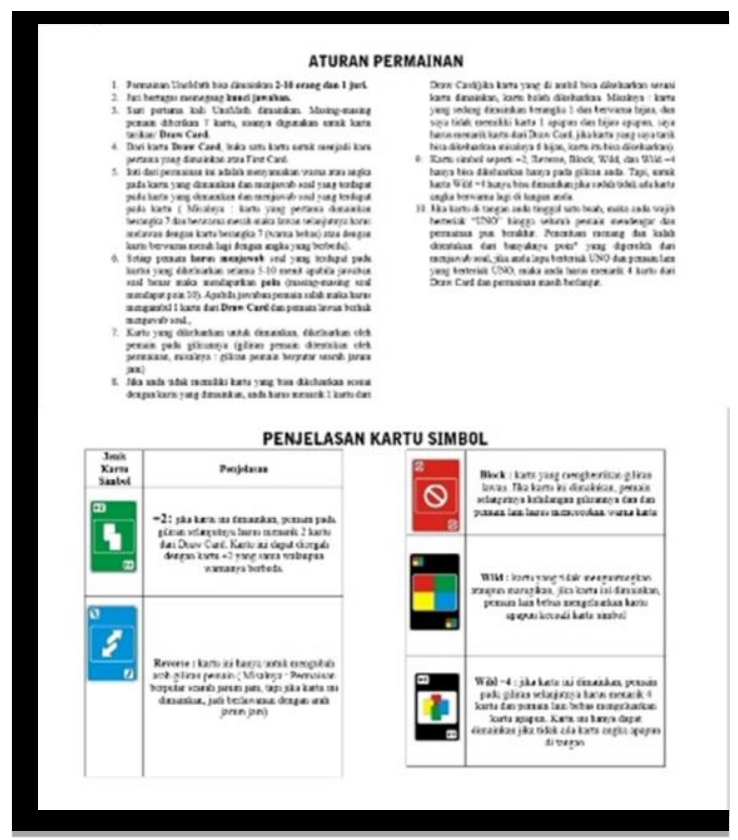

Gambar 1. Aturan Permainan Media UnoMath.

- 1 set kartu angka atau soal dari 0-9 (76 buah)

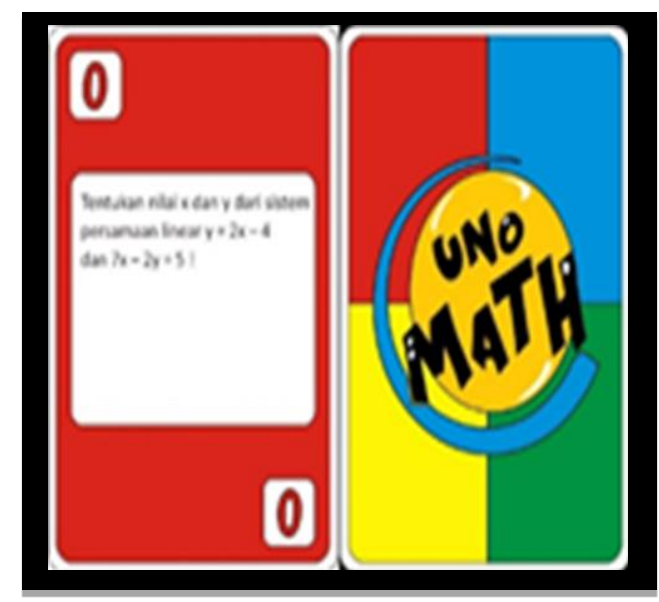

Gambar 2. Bagian Depan dan Bagian Belakang Kartu UnoMath.

- 2 lembar kunci jawaban

- 1 set kartu aksi (32 buah terdiri dari 8 kartu reserve, 8 kartu skip, 8 kartu draw, dan 8 kartu wild) 


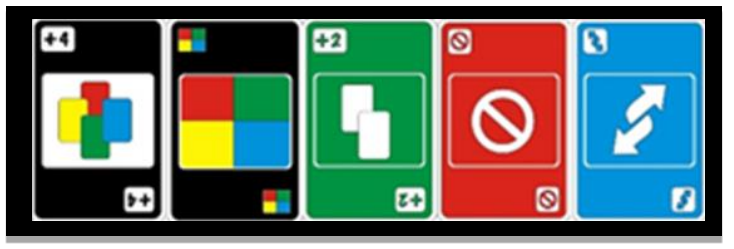

Gambar 3. Kartu Aksi.

4) Pembuatan Media Unomath

Pada proses ini peneliti menggabungkan rancangan pada tahap sebelumnya yaitu tahap desain. Semua komponen yang dimuat dalam media UnoMath didesain menggunakan CorrelDraw X7. Kartu UnoMath didesain dengan bentuk persegi panjang, dibuat dengan ukuran 8,5 × 5,5 $\mathrm{cm}$. Selanjutnya peneliti membuat background dengan meberikan warnawarna yang berbeda pada setiap kartu yang kemudian diberi angka dari 0-9 yaitu merah, kuning, hijau, dan biru. Untuk kartu aksi, peneliti mendesain hampir serupa dengan kartu UNO pada umunya namun sedikit dimodifikasi tampilannya. Kartu UnoMath terdiri dari 76 kartu angka/soal dan 32 kartu aksi dengan total kartu sebanyak 108 kartu.

Proses pembuatan media UnoMath berlangsung satu bulan dari bulan Desember 2019 sampai dengan Januari 2020. Setelah desain selesai kemudian dicetak menggunakan mesin cetak. Untuk kartu angka/soal dan kartu aksi peneliti menggunakan kertas AP 310. Untuk aturan permainan dicetak menggunakan HVS 80, berikut tampilan kartu media UnoMath.

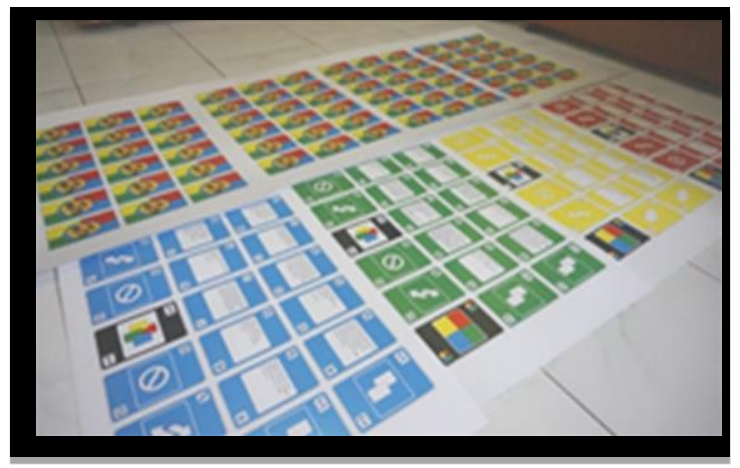

Gambar 4. Tampilan Kartu UnoMath.

\section{5) Validasi Desain}

Media pembelajaran UnoMath yang sudah selesai dibuat kemudian divalidasi oleh para expert untuk mengetahui kelayakan dan memperoleh saran untuk memperbaiki kesalahan dan kekurangan media UnoMath. Kegiatan ini dilakukan dengna menyerahkan media pembelajaran UnoMath dengan lembar validasi untuk diperiksa dan dinilai sebelum digunakan pada proses pembelajaran di kelas.

\section{6) Penerapan Media UnoMath}

Penerapan media UnoMath dalam pembelajaran dilakukan dengan bantuan RPP yang telah dibuat. Untuk petemuan pertama, kedua, dan ketiga pembelajaran berlangsung dengan menjelaskan materi persamaan linear dua variabel sesuai dengan RPP yang telah dibuat. Setelah semua materi tersampaikan, pada pertemuan selanjutnya pembelajaran di kelas menggunakan media UnoMath. Pembelajaran dimulai dengan menjelaskan permainan kartu UnoMath, aturan permainan, dan tujuan dari permainan kartu UnoMath itu sendiri. Setelah siswa memahami petunjuk dan aturan main kartu 
UnoMath, peneliti membagi siswa kedalam beberapa kelompok yang terdiri dari 5-7 orang dari 21 orang siswa, kemudian peneliti menunjuk salah satu siswa dalam setiap kelompok untuk menjadi juri yang memegang kunci jawaban dari soal-soal yang terdapat pada kartu UnoMath. Selama permainan berlangsung peneliti membimbing semua siswa yang sedang bermain kartu UnoMath. Setelah permainan berakhir, peneliti menunjuk slaah satu siswa untuk memberikan kesimpulan terhadap permainan kartu UnoMath dan materi persamaan linear dua variabel dan siswa yang lain memberikan tanggapan.

Walaupun siswa sudah memahami petunjuk permainan media UnoMath, peneliti harus menjelaskan sesekali kepada siswa yang terkadang masih lupa terhapad petunjuk dan aturan main media UnoMath. Selama kegiatan belajar mengajar sedang berlangsung siswa sangat antusias dan penuh semangat ketika sedang memainkan kartu UnoMath dan menjawab soal-soal yang terdapat pada media UnoMath.

\section{B. Respon Siswa terhadap Penerapan Media UnoMath}

Angket Respon siswa berisi 24 pernyataan yang terdiri dari 7 indikator. Angket tersebut disebarkan kepada 21 siswa kelas eksperimen yaitu kelas VIII C, adapun rekapitulasi perbandingan presentasi kumulatif angket respon siswa terhadap penerapan media UnoMath dalam pembelajaran matematika tiap indikatornya disajikan pada Tabel 1 berikut.
Tabel 1.

Rekapitulasi Presentase Angket Respon Siswa

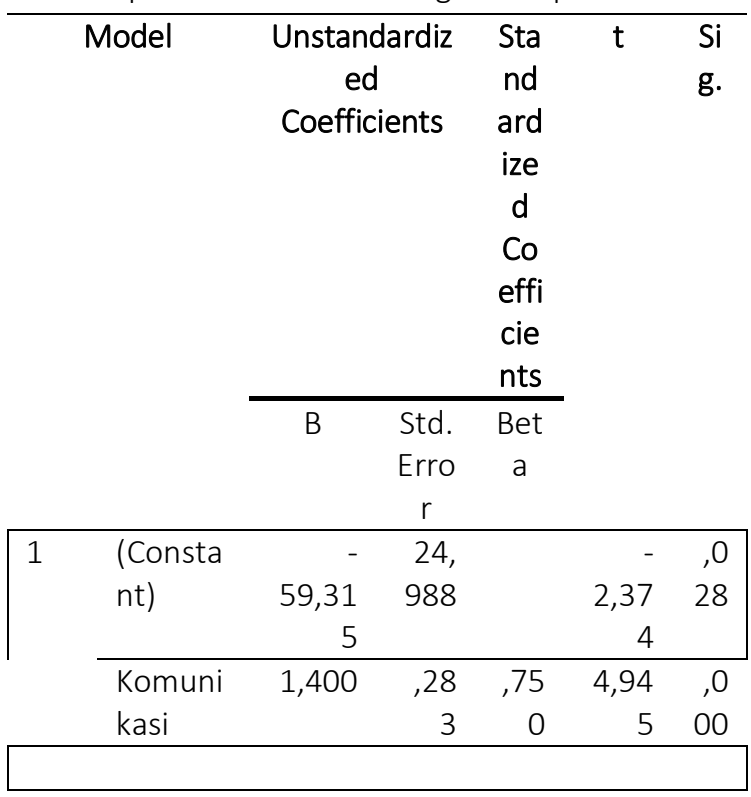

Berdasarkan Tabel 1, rata-rata respon siswa terhadap penerapan media UnoMath sebesar 72,87\% dengan kategori cukup baik. Rinciannya adalah kemudahan siswa dalam memahami materi $68,57 \%$ (cukup baik), siswa tidak terbebani dalam pembelajaran matematika 76,43\% (baik), ketertarikan siswa pada pembelajaran matematika 67,94\% (cukup baik), siswa aktif dalam pembelajaran 70,48\% (cukup baik), motivasi siswa dalam pembelajaran matematika 69,52\% (cukup baik), siswa memiliki keinginan yang lebih besar untuk mempelajari materi 74,29\% (cukup baik), dan siswa memiliki ketertarikan terhadap media pembelajaran UnoMath 82,86\% (baik).

\section{Pengaruh Penerapan Media UnoMath terhadap Kemampuan Komunikasi Matematis Siswa}

Tabel 2.

Hasil Uji Persamaan Regresi Linear Sederhana 


\begin{tabular}{|ccc|}
\hline Indikator & Presentase & Kriteria \\
\hline 1 & $68.57 \%$ & Cukup Baik \\
\hline 2 & $76.43 \%$ & Baik \\
\hline 3 & $67.94 \%$ & Cukup Baik \\
\hline 4 & $70.48 \%$ & Cukup Baik \\
\hline 5 & $69.52 \%$ & Cukup Baik \\
\hline 7 & $74.29 \%$ & Cukup Baik \\
\hline Kumulatif & $82.86 \%$ & Baik \\
\hline
\end{tabular}

Berdasarkan Tabel 2, untuk variabel kemampuan komunikasi matematis siswa, diperoleh hasil $t_{\text {hitung }}=4,945$ dengan derajat bebas $(\mathrm{df})=21-1=20$ dan tabel pada taraf kepercayaan 95\% atau signifikansi 5\% adalah 2,08596. Dengan demikian thitung $>$ ttabel $=4,945>$ 2,08596, maka HO ditolak atau Ha diterima. Jadi, dapat disimpulkan terdapat pengaruh yang signifikan penerapan media UnoMath terhadap peningkatan kemampuan komunikasi matematis siswa di SMP Negeri 3 Rajagaluh.

Tabel 3. Hasil Uji Koefisien Korelasi $\begin{array}{cccc}\text { Model } R & R & \begin{array}{c}\text { Adjusted } \\ \text { Std. Error } \\ \text { Square }\end{array} & \text { R Square the }\end{array}$

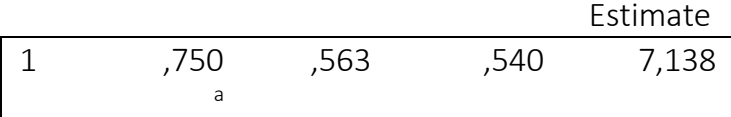

Berdasarkan Tabel 3, Pengaruh penerapan media UnoMath terhadap peningkatan kemampuan komunikasi matematis sebesar 0,563 atau 56,3\%. Hal ini berdasarkan uji koefisien determinasi, sehingga faktor lain yang mempengaruhi peningkatan kemampuan komunikasi matematis siswa adalah 43,7\%.

Tabel 4.
Nilai Statistik Deskriptif Hasil Posttest Kemampuan Komunikasi Matematis Siswa

\begin{tabular}{llllll|}
\hline Kelas & N & Min & Max & Mean & St.Dev \\
\hline VIII C & 21 & 51 & 85 & 64,00 & 10,521 \\
\hline VIII B & 31 & 15 & 54 & 33,42 & 11,938 \\
\hline
\end{tabular}

Tabel 5.

Hasil Uji Indepnedent Sample Test Nilai Posttest Kemampuan Komunikasi Matematis Siswa

\begin{tabular}{|lccc|}
\hline \multicolumn{1}{c}{} & \multicolumn{3}{c}{ t-test for Equality of means } \\
\cline { 2 - 4 } \multicolumn{1}{c|}{} & $\mathrm{T}$ & $\mathrm{df}$ & $\begin{array}{c}\text { Sig }(2- \\
\text { tailed })\end{array}$ \\
\hline $\begin{array}{l}\text { Variances } \\
\text { assumsed }\end{array}$ & 9,498 & 50 & 0,000 \\
\hline $\begin{array}{l}\text { Variances } \\
\text { not } \\
\text { assumed }\end{array}$ & 9,735 & 46,512 & 0,000 \\
\hline
\end{tabular}

Berdasarkan Tabel 5, hasil uji statistika menunjukkan bahwa terdapat perbedaan rata-rata kemampuan komunikasi matematis siswa yang diajar dengan menerapkan media UnoMath dengan yang tidak menerapkan media UnoMath. Hal ini dibuktikan dengan uji-t diperoleh nilai signifikansi untuk nilai posttest kemampuan komunikasi matematis siswa sebesar $0,000<0,05$. Selain itu berdasarkan Tabel 4, nilai rata-rata posttest kelas eksperimen sebesar 64,00 lebih baik daripada kelas kontrol sebesar 33,42.

\section{Pengaruh Penerapan Media UnoMath terhadap Kemandirian Belajar Siswa}

Tabel 6.

Hasil Uji Persamaan Regresi Linear Sederhana 


\begin{tabular}{|c|c|c|c|c|c|c|}
\hline & \multirow[t]{2}{*}{ Model } & \multicolumn{2}{|c|}{$\begin{array}{l}\text { Unstandar } \\
\text { dized } \\
\text { Coefficient } \\
\text { s }\end{array}$} & $\begin{array}{l}\text { Stand } \\
\text { ardize } \\
d \\
\text { Coeffi } \\
\text { cients }\end{array}$ & $t$ & $\begin{array}{l}\text { Si } \\
\text { g. }\end{array}$ \\
\hline & & $B$ & $\begin{array}{l}\text { Std } \\
\cdot \\
\text { Err } \\
\text { or }\end{array}$ & Beta & & \\
\hline 1 & $\begin{array}{l}\text { (Consta } \\
n t)\end{array}$ & $\begin{array}{r}8,44 \\
9\end{array}$ & $\begin{array}{r}12 \\
742\end{array}$ & & $\begin{array}{r}, 66 \\
3\end{array}$ & $\begin{array}{r}5 \\
1 \\
5\end{array}$ \\
\hline & $\begin{array}{l}\text { Kemand } \\
\text { irian }\end{array}$ & 797 & $\begin{array}{r}14 \\
0\end{array}$ & ,794 & $\begin{array}{r}5,6 \\
94\end{array}$ & $\begin{array}{r}0 \\
0 \\
0\end{array}$ \\
\hline
\end{tabular}

Berdasarkan Tabel 6, untuk variabel kemandirian belajar siswa, diperoleh hasil thitung $=5,694$ dengan derajat bebas $(\mathrm{df})=$ $21-1=20$ dan tabel pada taraf kepercayaan 95\% atau signifikansi 5\% adalah 2,08596. Dengan demikian thitung $>t_{\text {tabel }}=5,694>$ 2,08596, maka $\mathrm{H}_{0}$ ditolak atau $\mathrm{H}_{\mathrm{a}}$ diterima. Jadi, dapat disimpulkan terdapat pengaruh yang signifikan penerapan media UnoMath terhadap peningkatan kemandirian belajar siswa di SMP Negeri 3 Rajagaluh.

Tabel 7.

Hasil Uji Koefisien Korelasi

\begin{tabular}{|rrrrr|} 
Model & $\mathrm{R}$ & $\begin{array}{c}\mathrm{R} \\
\text { Square }\end{array}$ & $\begin{array}{c}\text { Adjusted } \\
\text { R Square }\end{array}$ & $\begin{array}{r}\text { Std. Error } \\
\text { of the } \\
\text { Estimate }\end{array}$ \\
\hline 1 & $\begin{array}{r}794 \\
\text { a }\end{array}$ &, 630 &, 611 & 2,911 \\
\hline
\end{tabular}

Berdasarkan Tabel 7, Pengaruh penerapan media UnoMath terhadap peningkatan kemandirian belajar siswa sebesar 0,630 atau 63,0\%. Hal ini berdasarkan uji koefisien determinasi, sehingga faktor lain yang mempengaruhi peningkatan kemandirian belajar siswa adalah $37,0 \%$.
Tabel 8.

Nilai Statistik Deskriptif Hasil Posttest Kemandirian Belajar Siswa

\begin{tabular}{llllll}
\hline Kelas & N & Min & Max & Mean & St.Dev \\
\hline VIII C & 21 & 75 & 90 & 80,90 & 4,668 \\
\hline VIII B & 31 & 62 & 78 & 68,65 & 4,673 \\
\hline
\end{tabular}

Tabel 9.

Hasil Uji Indepnedent Sample Test Nilai Posttest Kemandirian Belajar Siswa

\begin{tabular}{lccc|}
\hline & \multicolumn{3}{c}{ t-test for Equality of means } \\
\cline { 2 - 4 } \multicolumn{1}{c|}{} & $\mathrm{T}$ & $\mathrm{df}$ & $\begin{array}{c}\text { Sig }(2- \\
\text { tailed })\end{array}$ \\
\hline $\begin{array}{l}\text { Variances } \\
\text { assumsed }\end{array}$ & 9,287 & 50 & 0,000 \\
\hline $\begin{array}{l}\text { Variances } \\
\text { not assumed }\end{array}$ & 9,289 & 43,122 & 0,000 \\
\hline
\end{tabular}

Berdasarkan Tabel 9, hasil uji statistika menunjukkan bahwa terdapat perbedaan rata-rata kemandirian belajar siswa yang diajar dengan menerapkan media UnoMath dengan yang tidak menerapkan media UnoMath. Hal ini dibuktikan dengan uji-t diperoleh nilai signifikansi untuk nilai posttest kemandirian belajar siswa sebesar $0,000<0,05$. Selain itu berdasarkan Tabel 8 , nilai rata-rata posttest kelas eksperimen sebesar 80,90 lebih baik daripada kelas kontrol sebesar 68,65.

\section{Penutup}

Penerapan media pembelajaran matematika dengan metode permainan ini cukup efektif digunakan pada pembelajaran matematika. Selain UnoMath masih banyak media pembelajaran yang bisa digunakan untuk meciptakan suasana pembelajaran yang menyenangkan, nyaman, dan membuat siswa bahagia sehingga tujuan 
pembelajaran bisa tercapai dan kemampuan matematis siswa meningkat.

\section{Daftar Pustaka}

Afriansyah, E. A. (2013). Design Research: Place Value in Decimal Numbers Using Metric System. In International Seminar on Mathematics, Science, and Computer Science Education MSCEIS, Universitas Pendidikan Indonesia (UPI) Bandung.

Afriansyah, E. A., Puspitasari, N., Luritawaty, I. P., Mardiani, D., \& Sundayana, R. (2019, December). The analysis of mathematics with ATLAS. ti. In Journal of Physics: Conference Series (Vol. 1402, No. 7, p. 077097). IOP Publishing.

Anike, A., \& Handoko, H. (2018). Profil Kognitif Berfikir Kreatif Siswa pada Pembelajaran Matematika Model Jigsaw melalui Pendekatan Discovery Learning. Eduma: Mathematics Education Learning and Teaching, 7(1).

https://doi.org/10.24235/eduma.v7i1 .2900

Arsyad, A. (2011). Media Pembelajaran. Jakarta: Rajawali Pers.

Asmara, R., \& Afriansyah, E. A. (2018). Perbedaan Peningkatan Kemampuan Komunikasi Matematis Siswa antara Model Eliciting Activities dan Discovery Learning. Suska Journal of Mathematics Education, 4(2), 78-87.

Dewi, S. S. S., \& Afriansyah, E. A. (2018). Kemampuan Komunikasi Matematis
Siswa Melalui Pembelajaran

CTL. JIPMat, 3(2), 145-155.

Fahradina, N., dkk. (2014). Peningkatan Kemampuan Komunikasi Matematis dan Kemandirian Belajar Siswa SMP dengan Menggunakan Model Investigasi Kelompok. Jurnal Didaktik Matematika, 1.

Handoko, H. (2017). Pembentukan Keterampilan Berpikir Kreatif pada Pembelajaran Matematika Model Savi Berbasis Discovery Strategy Materi Dimensi Tiga Kelas X. Eduma: Mathematics Education Learning and Teaching, 6(1), 85. https://doi.org/10.24235/eduma.v6i1 .1711

Lestari, D. Munawaroh, M., \& Handoko, H. (2019). Pengaruh Penerapan Model Pembelajaran Bamboo Dancing Berbantuan Permainan Ular Tangga Untuk. Integral: Pendidkan Matematika, 10(1), 27-39.

Mulyo, M. R. G. T., Sari, A. F., \& Syarifuddin, A. (2019). Proses Berpikir Siswa Bergaya Kognitif Visualizer dalam Menyelesaikan Masalah TIMSS Non Geometri. Mosharafa: Jurnal Pendidikan Matematika, 8(1), 167178.

NCTM. (2000). Principles and Standards for School Mathematics. USA: NCTM.

Nurhayati, E. (2011). Bimbingan, Konseling \& Psikoterapi Inovatif. Yogyakarta: Pustaka Pelajar.

Nurhikmayati, I., \& Sunendar, A. (2020). Pengembangan Project Based 
Learning Berbasis Kearifan Lokal Berorientasi pada Kemampuan Berpikir Kreatif dan Kemandirian Belajar. Mosharafa: Jurnal Pendidikan Matematika, 9(1), 1-12.

Pannen, P., dkk. (2001). Konstruktivisme dalam Pembelajaran. Jakarta: PAUPPAI, Universitas Terbuka.

Rahmatin, R. (2016). Pengembangan Media Permainan Kartu UMATH (Uno Mathematics) dalam Pembelajaran Matematika pada Materi Pokok Operasi Bilangan Bulat. MATHEdunesa, 5.

Riduwan. (2010). Belajar Mudah untuk Guru, Karyawan, dan Peneliti Pemula. Bandung: Alfabeta.

Rizkianto, I., \& Santosa, R. H. (2017). Analisis buku matematika siswa SMP Kurikulum 2013. Mosharafa: Jurnal Pendidikan Matematika, 6(2), 229236.

Sumarno, U. (2003). Makalah Pembelajaran Matematika untuk Mendukung Pelaksanaan Kurikulum Berbasis Komptensi. Bandung: UPI.

Sumliyah. (2019). Penerapan Media Pembelajaran Cabri 3D pada Kemampuan Pemahaman Konsep Matematika SMK Materi Bangun Ruang. Integral: Pendidkan Matematika, 10, 16-27.

Sundawan, M. D., Irmawan, W., \& Sulaiman, H. (2019). Kemampuan Berpikir Relasional Abstrak Calon Guru Matematika dalam Menyelesaikan Soal-Soal Non-Rutin pada Topik
Geometri Non-Euclid. Mosharafa: Jurnal Pendidikan Matematika, 8(2), 319-330.

Sundayana, R. (2015). Media dan Alat Peraga dalam Pembelajaran Matematika. Bandung: Alfabeta.

Tarlina, W. H., \& Afriansyah, E. A. (2016). Kemampuan Berpikir Kreatif Siswa Melalui Creative Problem Solving. Eduma: Mathematics Education Learning and Teaching, 5(2), 42-51.

TIMSS. (2011). International Result in Mtahematics. Lynch School of Education, Boston College.

\section{Riwayat Hidup PenUlis}

\section{Asep Robiana, S.Pd.}

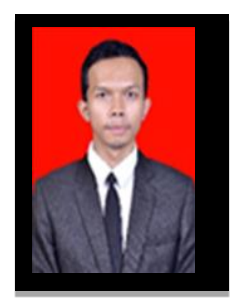

Lahir di Majaelngka, 14 Mei 1996. Menyelesaikan program S1 pada jurusan tadris matematika Institut Agama Islam Negeri (IAIN) Syekh Nurjati Cirebon dan lulus pada tahun 2020.

\section{Hendri Handoko, M.Pd}

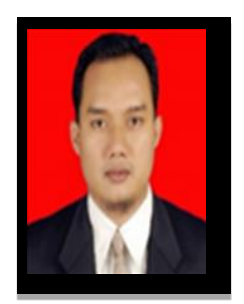

Lahir di Brebes, 2 Agustus 1981. Staf pengajar di Institut Agama Islam Negeri (IAIN) Syekh Nurjati Cirebon. Studi S-1 Pendidikan Matematika di Universitas Muhammadiyah Surakarta (UMS), lulus tahun 2006; S-2 Pendidikan Matematika di Universitas Negeri Semarang (UNNES), lulus tahun 2013. 